\title{
TRANZICIJA IZ HRANITELJSTVA U SAMOSTALNOST - PRIKAZ ISTRAŽIVANJA
}

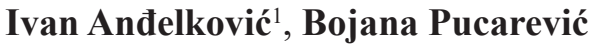 \\ Univerzitet u Nišu, Filozofski fakultet u Nišu, Departman za socijalnu politiku i \\ socijalni rad
}

\begin{abstract}
Apstrakt: Rad sadrži kritički prikaz skorijih istraživanja faktora uspešnog osamostaljivanja dece iz hraniteljskih porodica. Pregled obuhvata studije sprovedene u različitim kulturnim sredinama, poput Amerike, Nemačke, Norveške, Koreje, Izraela i naše zemlje. Cilj nam je da ukažemo na dostignuća do kojih se došlo u ovoj oblasti i da istaknemo značaj onih rezultata koji su se potvrdili u većem broju istraživanja - konkretno, uticaja socijalne podrške na uspešnost osamostaljivanja. Osim toga što se pokazao kao kulturno univerzalan, ovaj rezultat dobijen je kako u studijama koje su se bavile uspešnim tranzicijama, tako i u onim koje su se fokusirale na teškoće sa kojima se suočavaju mladi pri napuštanju smeštaja. Prikazom su obuhvaćena i istraživanja koja mogu da ponude odgovor na pitanje od čega zavisi sposobnost i spremnost adolescenata da grade i koriste socijalnu podršku prilikom osamostaljivanja. U radu se razmatraju i nedostaci navedenih istraživanja i predlažu moguće dalje istraživačke perspektive u vezi sa problemom tranzicije, kako bi rezultati naučnih studija bili od veće koristi za planiranje i sprovođenje intervencija u praksi.
\end{abstract}

Ključne reči: hraniteljstvo, adolescenti, osamostaljivanje, socijalna podrška

\section{Uvod}

Cilj ovog rada jeste da prikaže u kojoj meri su dosadašnja istraživanja uspela da utvrde koji faktori su povezani sa uspešnošću dece da napuste hraniteljski smeštaj i započnu samostalni život. S obzirom da je spremnost dece da napuste hraniteljstvo $\mathrm{u}$ fokusu našeg pregleda, predstavljena istraživanja biće podeljena $\mathrm{u}$ dve grupe - na ona koja su se bavila adolescentima neposredno nakon napuštanja smeštaja i ona koja su se bavila decom dok su ona u sistemu zaštite. Razlog koji nas navodi na ovakvu podelu u našem pregledu ogleda se u dve činjenice: s jedne strane, o kvalitetu spremnosti može se precizno zaključivati na osnovu uspeha adaptacije na samostalan život, koji u tom slučaju služi kao objektivni pokazatelj ispitivanog konstrukta, dok s druge strane, možemo da pretpostavimo da su na nivo i kvalitet spremnosti za samostalan život uticali uslovi života kojima je dete bilo izloženo mnogo pre samog

\footnotetext{
${ }^{1}$ Ivan.andjelkovic@filfak.ni.ac.rs
} 
trenutka napuštanja sistema zaštite. Nakon prikaza najrelevantnijih rezultata ove dve grupe istraživanja biće diskutovano u kojoj meri su autori do sada integrisali ova saznanja kako bi se što preciznije odgovorilo na pitanje od čega zavisi uspeh tranzicije iz hraniteljstva u samostalnost. Takođe, ukazaćemo na nedostatke u povezivanju dosadašnjih rezultata, sa ciljem da ponudimo adekvatniji pristup istraživanju ovog problema u budućim istraživanjima.

\section{Prikaz istraživanja}

\section{Teškoće i resursi adolescenata pri napuštanju hraniteljstva}

Prikaz ćemo započeti grupom istraživanja koja su se bavila adolescentima nakon napuštanja hraniteljskog smeštaja. Ova istraživanja imala su za cilj da, kao prvo, ustanove sa kojim teškoćama se susreću mladi koji napuštaju sistem socijalne zaštite u odnosu na njihove vršnjake iz opšte populacije, i kao drugo, da utvrde šta mladi ocenjuju kao zanačajan resurs u procesu tranzicije iz sistema u samostalnost.

Iako istraživači iz ove grupe imaju sličan cilj, videćemo da postoje značajne razlike u pogledu izbora aspekta tranzicije koji se ispituje, kao i metodologije koja se primenjuje. Pre svega, osvrnimo se na to zašto autori smatraju da je ovaj period života posebno značajan za decu iz hraniteljskih porodica. Brenda Morton navodi da se kompleksnost sa kojom se suočavaju ovi adolescenti sastoji iz „dve simultane tranzicije - jedne iz zaštite, brige i supervizije sistema za zaštitu dece u poziciju autonomije i odgovornosti, i druge iz detinjstva u odraslo doba“ (Morton, 2017: 1). Sam prelazak u odraslo doba prepoznat je kao turbulentan razvojni period. Arnet (Arnet, 2000) naziva ovaj period života „odraslo doba u nastajanju (eng. emerging adulthood)“ i opisuje ga kao ,vreme u životu kada su mnogi različiti pravci i dalje mogući, kada se malo toga odlučilo u vezi sa budućnošću, a kada su individualne mogućnosti za samostalnim istraživanjem životnih opcija veće nego u bilo kom drugom trenutku u životu" (Arnet, 2000: 469). Autor smatra da je odlaganje tranzicije u odraslo doba do kasnih dvadesetih godina života značajno zato što ostavlja slobodu za ispitivanje različitih životnih puteva. Konačni prelazak u odraslo doba Brenda Morton definiše pomoću tri specifična kriterijuma: preuzimanje odgovornosti za sebe, donošenje nezavisnih odluka i ostvarivanje finansijske samostalnosti. Za decu koja su provela duži period u strukturisanom sistemu zaštite u kojem su odrasli donosili odluke umesto njih, život u manje strukturisanom, kompleksnom okruženju predstavlja veliki izazov za koji nisu dobro pripremljeni (Morton, 2017). Razlog nedovoljne pripremljenosti nalazimo u činjenici da pomenuta grupa mladih nema ovaj važan period života o kome je u prethodnom delu teksta bilo reči (,odraslo doba u nastajanju“), što znači da ovi adolesceniti nisu u mogućnosti da eksperimentišu sa različitim odlukama u vezi sa mogućim životnim putevima, i da se pritom osećaju bezbedno jer imaju podršku svoje porodice koja im omogućava da odustanu od određenih izbora, da se predomisle i oprobaju se u nečemu drugom. Možemo pretpostaviti postojanje još jednog razloga - odnos dece i hranitelja razlikuje se od odnosa dece i roditelja u biološkim porodicama i u tome što sistem 
socijalne zaštite predstavlja medijatora tog odnosa, odnosno možemo reći da je sistem treći član tog odnosa koji se brine da dete ima zadovoljene sve osnovne potrebe nužne za zdrav fizički i mentalni razvoj, a da pri tom dete nije u obavezi da preuzme odgovornost za uspeh u obrazovanju i kvalitetnoj pripremi za sticanje zaposlenja. Bilo bi logično očekivati da se mlade osobe, pogotovu one koje ne gledaju daleko u budućnost, u ovakvim uslovima mogu „olenjiti“. Kada spojimo dva navedena razloga imamo sliku adolescenta koji iz sigurne sredine u kojoj se osećao bezbrižno, naglo prelazi u svet u kome nema prostora da isprobava različite načine snalaženja, a da ga u slučaju neuspeha čeka ,sigurnosna mreža“ u vidu porodice koja će uvek biti tu kada zatreba. Kako se pomenute razlike u uslovima odrastanja manifestuju u kvalitetu života nakon navršenog punoletstva može se videti iz sistematskog prikaza dvadeset istraživanja koje su sproveli skandinavski autori (Kaariala \& Hiilamo, 2017), u kome se porede teškoće adolescenata iz hraniteljskih porodica i adolescenata iz opšte populacije u pogledu devet kategorija: teškoće u samostalnom izdržavanju, teškoće u obrazovanju, psihološki problemi, kriminalitet, maloletnička trudnoća, smrtnost, suicidalno ponašanje, zloupotreba alkohola i narkotika, i primanje invalidske penzije. Pokazalo se da su osobe koje su kao deca bile u sistemu zaštite značajno češće izložene svim navedenim problemima. Grupa autora (Olson i sar., 2017) ispitivala je psihološke razlike koje mogu da objasne ovako drastično niži nivo prilagođavanja na samostalni život. Ovi autori su ustanovili da se mladi koji su napustili hraniteljstvo razlikuju od kontrolne grupe u pogledu veština za donošenje odluka. Konkretnije, razlike su se pokazale u pogledu identifikovanja alternativa, izboru alternativa i evaluaciji odluka. Razlika nije bilo u pogledu sposobnosti da se uvidi problem i identifikuju rizici i posledice. Analiza rezultata pokazuje da se mladi koji su bili u sitemu zaštite razlikuju upravo u pogledu onih aspekata koji su važni za sam proces donošenja odluka, i u pogledu analize prethodnih odluka, što zapravo predstavlja učenje iz iskustva.

U ovu grupu uvrstili smo i istraživanja koja ne porede ispitivanu populaciju sa kontrolnom grupom, već kvalitativnim pristupom u istraživanju omogućavaju da se sazna šta je to što sami adolescenti koji napuštaju hraniteljstvo smatraju važnim za ovu tranziciju.

Istraživanje sprovedeno u Izraelu (Sulimani-Aidan, 2017) imalo je za cilj da ispita sa kojim se izazovima i teškoćama suočavaju mladi koji napuštaju zaštitu. Tri teme su se izdvojile kao dominantne u opisima ispitanika. Prva predstavlja slabe i nepodržavajuće socijalne veze, što obuhvata osećaj usamljenosti i neadekvatne međuljudske odnose, nedostatak socijalne podrške i usmeravanja, i negativni uticaj prošlih i sadašnjih odnosa sa ljudima. Druga tema odnosi se na kompleksan odnos sa biološkom porodicom, i takođe uključuje tri podteme: zavisnost porodice od mlade osobe, nedostatak podrške i vere u aspiracije osobe, i nedovoljno emotivne i praktične podrške u donošenju odluka o budućnosti. Treća tema predstavlja loš materijalni status, koji je povezan kako sa ekonomskim teškoćama tako i sa problemima u obrazovanju. Autor zaključuje da je odsustvo podrške osnovni nedostajući činilac koji otežava izlazak iz sistema zaštite.

Na slične zaključke navode rezultati istraživanja sprovedenog u Koreji (Nho i sar., 2017), iako se ovo istraživanje zasnivalo na studiji slučaja mladih koji su uspeš- 
no prešli iz hraniteljstva u odraslo doba. Autori primećuju da se kod njihovih ispitanika izdvajaju dve glavne teme: socijalna podrška i individualni faktori. U okviru socijalne podrške razlikovala se neformalna podrška koja je dolazila od strane ,značajnih drugih" u vidu pružanja pomoći, davanja saveta, ili mogućnosti da podele svoja iskustva sa ljudima koji su prošli kroz slične životne okolnosti, i formalna podrška koju su pružale vladine institucije ili privatne organizacije u vidu materijalne pomoći i podrške u obrazovanju. Individualni faktori obuhvatali su studiranje, dobro uočavanje kojim putem treba ići u životu, želja da se bude jednak sa ostalim vršnjacima, rešenost da se preživi u teškim okolnostima, vera u sebe uz prihvatanje pomoći od drugih i otvoreno pričanje o prošlosti, ali uz rešenost da prošlost ostaje iza, a da je fokus na razmišljanju o budućnosti.

Alana Kinarski (Kinarsky, 2017) ispitivala je iskustva studenata iz SAD koji su kao deca bili u hraniteljskim porodicama. Autorka takođe zaključuje da je ovim studentima potrebna kontinuirana podrška u sticanju osnovnih životnih veština, kao što su upravljanje finansijama i obezbeđivanje stalnog mesta prebivališta. Skoro polovina njenih ispitanika bila je primorana da se slabije hrani i preskače obroke zbog lošeg materijalnog stanja. Ovi studenti su se ustručavali da potraže pomoć kada im je bila potrebna, iako su imali tu mogućnost u studentskim domovima u kojima su boravili. U diskusiji sličnih rezultata do kojih je došla u svom istraživanju, Brenda Morton (2017) ponudila je moguće objašnjenje ovog odbijanja da se potraži pomoć. Naime, autorka je ustanovila da je osnovni motiv u odgovorima njenih ispitanika rešenost da budu nezavisni. Ova rešenost se manifestovala kod studenata u učionici kao apatija, odsustvo motivacije i nisko samopouzdanje, što je za posledicu imalo loše akademsko postignuće. Odsustvo traženja pomoći bilo je prouzrokovano osećanjem ponosa i željom da se uklopi i bude jednak sa ostalima. Racionalizacija koja je pratila ovu želju glasila je „ako mogu drugi, mogu i ja”. Ovakve postupke autorka objašnjava verovanjem ovih adolescenata da je oslanjanje na druge rizično. Iskustava promena smeštaja, škola i komšiluka, učinila su da ovi mladi vide druge ljude kao prolazne u njihovim životima, kao ljude koji neće uvek biti tu kada je potrebno. Kao posledicu oni razvijaju model preživljavanja zasnovan na samodovoljnosti. Iako nekad koristan, ovakav pristup životu onemogućava ih da vide da nezavisnost od sistema zaštite ne znači da su sada spremni da se potpuno sami nose sa svim izazovima odraslog života.

Iz rezultata do sada predstavljenih istraživanja jasno se vidi da je prisustvo socijalne podrške jedan od najznačajnih faktora koji utiče na uspešnost tranzicije u odraslo doba. Ključna uloga ovog činioca potvrđena je i u istraživanjima koja su se bavila uspešnim tranzicijama i u onima koja su se bavila teškoćama na koje nailaze mladi pri izlasku iz sistema zaštite. Osim identifikacije socijalne podrške kao važnog protektivnog faktora, značajan nalaz jeste to da veliki broj adolescenata iz ove populacije ima teškoća da obezbedi sebi socijalnu podršku. Dok neki autori završavaju svoje diskusije zaključcima da je potrebno uvesti veći broj programa koji će obezbediti podršku ovoj populaciji (Kinarsky, 2017), manji broj autora ide korak dalje u diskusiji i nudi hipotetičko objašnjenje ovakvog ponašanja. Ovi autori pronalaze uzroke $u$ iskustvima koja datiraju znatno pre napuštanja sistema zaštite, tačnije, do- 
godila su se i pre samog smeštaja u hraniteljske porodice (Kaariala, Hiilamo, 2017). Ovo objašnjenje našlo je i empirijsku potvrdu u većem broju istraživanja (Turney \& Wildeman, 2017; Fridell i sar., 2016) koja su potvrdila povezanost između traumatskih iskustava iz ranog detinjstva i nepovoljnih ishoda hraniteljstva u adolescenciji. $\mathrm{S}$ obzirom da samo iskustvo izmeštanja iz biološke porodice predstavlja traumatski događaj za svako dete, i da je ono povezano sa prethodnim neadekvatnim roditeljskim staranjem, postavlja se pitanje kako jedan broj dece nakon boravka u hraniteljskoj porodici ima kapacitet da razvija i koristi socijalnu podršku, dok drugi broj tu sposobnost nije izgradio. Kako bi se potražio odgovor na ovo pitanje, potrebno je baviti se faktorima kojima je dete izloženo u toku boravka u hraniteljskoj porodici, a koji mogu biti u vezi sa pomenutim pozitivnim ili negativnim ishodima.

\section{Faktori povezani sa pozitivnim ishodima hraniteljstva}

Grupa istraživanja koju ćemo sada predstaviti bavila se utvrđivanjem faktora koji su povezani sa dobrostanjem dece koja se nalaze na hraniteljstvu. U ovoj grupi nalaze se istraživanja koja na različite načine konceptualizuju dobrostanje dece. U diskusiji njihovih rezultata analiziraćemo koji vid konceptualizacije je najpogodniji kada je spremnost za osamostaljivanje u pitanju. Gumans i saradnici (Goemans i sar, 2016) ispituju povezanost karakteristika deteta (uzrast, pol, razlog izmeštanja iz biološke porodice, broj i vrstu pretodnih smeštaja, dužinu trenutnog smeštaja, i prisustvo problema u ponašanju), karakteristika hraniteljske porodice (srodničko ili nesrodničko hraniteljstvo, sastav hraniteljske porodice, broj biološke dece hranitelja, broj druge dece koja su na hraniteljstvu u istoj porodici, i razmišljanje hranitelja o napuštanju uloge hranitelja), i karakteristika smeštaja (plan reunifikacije sa biološkom porodicom, intervencije centra koji nadgleda hraniteljstvo usmereno na decu kao i intervencije usmerene na hranitelje, i kontakt deteta sa biološkom porodicom) sa prisustvom eksternalizujućih i internalizujućih problema u ponašanju i količinom prosocijalnog ponašanja kod dece koja su na smeštaju. Rezultati pokazuju da starija deca i deca sa manje prethodnih smeštaja imaju manje problema; deca koja su na nesrodničkom hraniteljstvu, i čiji hranitelji razmišljaju o prekidanju hraniteljske prakse pokazuju veći nivo problema; konačno, veći broj intervencija usmerenih na decu i na hranitelje u pozitivnoj vezi je sa eksternalizujućim i internalizujućim problemima u ponašanju. Značajno više prosocijalnog ponašanja pokazala su deca koja se nalaze na srodnčkom hraniteljstvu, bez prisustva biološke dece hranitelja u slučaju kada hranitelji ne razmišljaju o okončanju hraniteljstva. Sa druge strane, deca kod kojih postoji plan reunifikacije sa biološkom porodicom pokazuju manje prosocijalnog ponašanja. Primenom regresione analize, autori su utvrdili da prisustvo intervencija centra objašnjava največi deo varijanse kriterijumskih varijabli - veći broj intervencija predviđao je više problema u ponašanju kod dece.

Upravo se u ovom glavnom rezultatu do kog su došli autori ogleda osnovni nedostatak ove vrste istraživanja. Naime, istraživanje je transverzalnog tipa i po prirodi korelativno, tako da je nemoguće empirijski odrediti koje varijable predstavljaju uzroke, a koje posledice. Jedino je moguće posmatrati kako promene u jednoj grupi 
varijabli prate promene u drugoj, dok se o uzročno posledičnim vezama može samo govoriti na osnovu teorijskih pretpostavki.

U istraživanju koje je takođe imalo za cilj da ispita koji faktori utiču na prisustvo problema u ponašanju kod ove dece Peri i Prajs (Perry \& Price, 2018) ustanovili su da viši nivo stresa kod hranitelja i više problema u ponašanju koje manifestuje drugo dete koje se takođe nalazi u hraniteljskoj porodici, predviđaju više internalizujućih problema u ponašanju ispitivanog deteta. $\mathrm{Na}$ veći broj eksternalizujućih problema u ponašanju utiče veći broj prethodnih domskih smeštaja (eng. group placements), zatim viši nivo stresa hranitelja, različita etnička pripadnost hranitelja i deteta i nesrodničko hraniteljstvo. I u ovom slučaju teško je zaključivati o uzročno posledičnim vezama, tako da ostaje nejasno da li veći nivo stresa hranitelja utiče na probleme u ponašanju deteta, ili su hranitelji pod većim stresom zato što deca manifestuju puno problema. Takođe, nejasno je da li je veći broj prethodnih smeštaja uticao na pojavu problema u ponašanju, ili su problemi u ponašanju bili razlog zbog kog je dete često menjalo smeštaj.

Naredna istraživanja od posebnog su značaja za ovaj pregled, s obzirom da kod dece ispituju psihološku karakteristiku koja je značajna za proces izgradnje i korišćenja socijalne podrške. Konkretno, u ovim istraživanjima dobrostanje dece ne operacionalizuje se pomoću prisustva, odnosno odsustva, problema u ponašanju ili prosocijalnog ponašanja, već preko kvaliteta afektivne vezanosti deteta za primarnog hranitelja (uglavnom su to osobe ženskog pola). S obzirom da je varijabla koja se pokazala kao najznačajniji prediktor afektivne vezanosti dece u biološkim dijadama majka - dete, mentalno stanje majke u odnosu na afektivnu vezanost (van Ijzendoorn, 1995), pod čime se podrazumeva način obrade misli i osećanja koja se odnose na sopstvena iskustva afektivnog vezivanja, Meri Dozijer i saradnici (Dozier i sar, 2001) pokušali su da ustanove da li će isto važiti i u odnosu hranitelj-dete. U istraživanju sprovedenom na uzorku od pedesetoro dece, uzrasta do dvadeset meseci i njihovih hraniteljki pokazalo se da kada se bebe smeste u hraniteljsku porodicu do uzrasta od godinu i po dana, one uspevaju da organizuju svoje afektivno ponašanje oko dostupnih hranitelja. Takođe, obrazac afektivne veze hraniteljki pokazao se kao značajan prediktor afektivne veze dece. Preciznije, svega 21\% sigurnih hraniteljki imalo je dezorganizovano vezanu decu, dok je 62,5\% nesigurnih majki imalo dezorganizovanu decu. Ovaj rezultat ukazuje na to da je sigurna vezanost hranitelja od suštinske važnosti u prevazilaženju negativnih iskustava kojima su ova deca bila izložena u svojim biološkim porodicama.

U narednom istraživanju koje su sproveli Dozijer i Stoval (Dozier \& Stoval, 2004) ispitivana je prediktivna vrednost kvaliteta afektivne veze hranitelja, uzrasta na kome se dogodio smeštaj, i prethodnih negativnih iskustava koja su deca doživela (ovu varijablu autori su nazvali kumulativni skor rizika, i ona je obuhvatala fizičko zlostavljanje, broj prethodnih smeštaja, i prenatalnu izloženost psihoaktivnim supstancama). Deca na smeštaju bila su uzrasta između 5 i 28 meseci, i praćena su u periodu od tri do četiri meseca nakon smeštaja. Rezultati su pokazali da deca mlađa od 12 meseci na početku smeštaja (u prva dva meseca) brže pokazuju jasniju sliku jednog obrasca, i to najčešće sigurnog. Starija deca se češće povlače od hra- 
nitelja kada su povređena, uplašena ili kada su bila razdvojena, i pokazuju manje koherentnu sliku jednog obrasca afektivne vezanosti - njihovo ponašanje predstavlja mešavinu ponašanja karakterističnih za različite obrasce afektivne vezanosti. I u ovom istraživanju deca smeštena kod sigurnih hranitelja pokazala su više ponašanja karakterističnog za sigurni obrazac i koherntniju sliku ispoljenog obrasca. Još jedan značajan rezultat jeste prediktivna vrednost skora rizika - viši skor predviđao je manje koherentnog i manje sigurnog ponašanja. Sumirajući rezultate dva navedena istraživanja, autori zaključuju da ostaje nejasno da li efekti uzrasta na kome se dogodio smeštaj reflektuju dužinu vremena provedenog u problematičnom okruženju, uzrasta na kome se primarna veza prekinula, ili uzrasta na kome se formira nova afektivna veza (Stovall-McClough \& Dozier, 2004).

O nedostacima prikazanih istraživanja govori i grupa autora koja je u skorije vreme sprovela ispitivanje povezanosti iskustava dece pre smeštaja i senzitivnosti hranitelja sa kvalitetom afektivne veze dece na hraniteljstvu u Nemačkoj (Bovenschen i sar., 2016). Autori primećuju da se većina dosadašnjih studija iz ove oblasti bavila decom na uzrastu do dve godine. Uz isticanje značaja pozitivnih rezultata o tome da se ovako mala deca uspešno prilagođavaju i formiraju sigurne veze uz dostupne hranitelje, autori zapažaju da do sada nisu istraživana deca koja se nalaze duže na smeštaju, zatim deca koja kasnije dolaze na smeštaj, i da je pažnja posvećivana samo bihevioralnom nivou afektivne vezanosti. Autori navode da je pretpostavka o postojanju dva nivoa afektivne vezanosti, tačnije dva nivoa unutrašnjih radnih modela sebe i drugih, potvrđena u većem broju studija, i da se pokazalo da ta dva nivoa - bihevioralni i reprezentacioni, funkcionišu nezavisno jedan od drugog (Bretherton \& Munholland, 2008; Spangler \& Zimmermann, 1999, prema Bovenschen i sar., 2016). Bihevioralni nivo predstavlja ponašanje deteta u odnosu na jednu osobu, dok reprezentacioni predstavlja generalizovani stav deteta u odnosu na emotivno vezivanje za važne figure $u$ životu, i on se razvija tek kada dete ovlada govorom. Istraživanja su pokazala da su u opštoj populaciji dece ova dva nivoa afektivne vezanosti u korelaciji (Bretherton i sar., 1990; Smeekens i sar., 2009., prema Bovenschen i sar., 2016). Kada su u pitanju deca na hraniteljstvu, međutim, postavlja se pitanje da li su različita iskustva iz biološke i hraniteljske porodice uticala na to da se ovi nivoi afektivne veze razlikuju. Rezultati su pokazali na bihevioralnom nivou da je ponašanje hranitelja, konkretno, podržavajuće prisustvo i poštovanje autonomije deteta, povezano pozitivno sa sigurnim obrascem vezanosti. Ovaj obrazac je takođe negativno povezan sa mentalnom bolesti bioloških roditelja. Na reprezentacionom nivou dezorganizacija kod dece bila je povezana sa iskustvima pre smeštaja, i to konkretno sa fizičkim zlostavljanjem, dok nije bilo veze sa emotivnim zlostavljanjem i zanemarivanjem. Između ponašajnog i reprezentacionog nivoa nije bilo korelacije čime je potvrđena pretpostavka da negativna iskustva iz bioloških porodica, iako ne sprečavaju decu da se ponašaju na siguran način sa hraniteljima, ostavljaju negativan trag na dubljem nivou. Za razliku od prethodnih istraživanja, u ovom slučaju ispitivana deca su imala niži nivo sigurne veze u odnosu na opštu populaciju. Autori objašnjavaju ovu razliku time što se njihov uzorak sastojao od starije dece, na uzrastu od osam godina, i ističu potrebu da se naredna istraživanja bave takođe starijom 
decom jer su očigledno ona pod većim rizikom u odnosu na decu koja ulaze na smeštaj u prve dve godine života.

\section{Diskusija}

Sada kada smo prikazali dve grupe istraživanja, razmotrićemo u kojoj meri se zaključci do kojih su njihovi autori došli mogu integrisati, odnosno na koji način rezultati jedne grupe mogu doprineti boljem razumevanje rezultata druge grupe. Osnovni uvid do koga su došli autori koji su ispitivali uspešnost napuštanja hraniteljskih porodica jeste da socijalna podrška predstavlja važan oslonac adolescentima pri tranziciji u samostalnost. Ovaj rezultat, koji se pokazao kao kulturno univerzalan, ne predstavlja iznenađenje, pogotovu kada se ima u vidu kompleksnost tranzicije koju prolaze deca pri napuštanju sistema zaštite i potpunog preuzimanja odgovornosti za sopstveni život, o čemu je bilo reči na početku ovog rada (Morton, 2017; Arnet, 2000). Kada se uzme u obzir i rezultat prema kome ovi adolescenti imaju teškoće pri donošenju odluka (Olson i sar., 2017) postaje još jasnije da je mladima pri osamostaljivanju potrebna socijalna podrška kako bi imali s kim da se konsultuju u periodu kada moraju da donesu veliki broj odluka u kratkom procesu osamostaljivanja. Iako važan resurs, socijalnu podršku, međutim, veliki broj ovih adolescenata ne uspe da izgradi. Ovaj rezultat potvrđen je i $\mathrm{u}$ jednom od opširnijih istraživanja sprovedenog u našoj zemlji „Traženje pomoći je sposobnost koju mladi za sada izgleda nisu razvili ili pak sebe smatraju neuspešnim u tome. Nezavisno od toga što gotovo svi ispitani mladi procenjuju da su im u neposrednom okruženju dostupni pomoć i podrška, samo jedna mlada osoba je izjavila da traži pomoć uvek kada joj je to potrebno. Ostali su naveli da ne vole da traže pomoć, već se radije oslanjaju na sebe i sopstvene snage kada naiđu na teškoće" (Žegarac, 2014: 361). Istraživanja koja su se bavila mladima nakon tranzicije nisu ustanovila po čemu se razlikuju oni koji su uspešni u formiranju podržavajućih međuljudskih odnosa od onih koji u tome ne uspevaju. Neki autori (Kaariala, Hiilamo, 2017) jesu konstatovali da traumatska iskustva iz bioloških porodica imaju dalekosežni sputavajući efekat na socijalno funkcionisanje u mladosti, ali nisu odgovorili na pitanje koje se nameće, a to je: kako određeni broj dece prevaziđe posledice ranih negativnih iskustava, i formira adekvatne društvene $\mathrm{i}$ emotivne odnose u mladosti? Drugim rečima, ovi autori nisu tragali za faktorom koji može imati reparativni efekat u razvoju dece sa ranim traumatskim iskustvima. Bez identifikacije ovog faktora, rezultati ovih istraživanja nisu od velikog značaja za kreiranje i sprovođenje intervencija u praksi sa ciljem da se mladi što bolje pripreme za samostalan život nakon hraniteljstva. Zbog ovog nedostatka, potrebno je analizirati istraživanja koja su se bavila decom za vreme njihovog boravka u hraniteljskim porodicama i ispitivala povezanost karakteristika dece i faktora iz sredine u kojoj deca borave. Videli smo da su neka istraživanja ustanovila povezanost između karakteristika deteta, karakteristika hraniteljske porodice, karakteristika smeštaja i broja intervencija centra za socijalni rad, sa količinom problema u ponašanju i količinom prosocijalnog ponašanja koje manifestuju deca na smeštaju. Sami autori navode kao nedostatak svojih rezultata činjenicu da je nemoguće govoriti o kauzalnim vezama, pre 
svega kada je reč o karakteristikama poput stresa hranitelja, broja intervencija centara, broja prethodnih smeštaja i količine problema u ponašanju kod dece. Iz ustanovljenih korelacija ne može se zaključiti da li je više problema kod dece posledica čestih promena smeštaja, visokog nivoa stresa kod hranitelja, čestih poseta stručnih radnika koje se mogu doživeti kao vrsta stigmatizacije, ili su upravo izraženi problemi kod dece uzrok češćih promena porodica, stresa kod hranitelja i poseta stručnih radnika. U ovim istraživanjima, međutim, postoje rezultati koji po našem mišljenju zavređuju više pažnje nego što su im sami autori poklonili. U njih bismo uvrstili sledeće: manje problema je prisutno kod starije dece, dece sa manje prethodnih smeštaja, dece na srodničkom smeštaju i dece čiji hranitelji ne razmišljaju o prekidanju hraniteljske prakse; značajno više prosocijalnog ponašanja pokazala su deca koja se nalaze na srodnčkom hraniteljstvu, bez prisustva biološke dece hranitelja u slučaju kada hranitelji ne razmišljaju o okončanju hraniteljstva, i kada ne postoji plan reunifikacije sa biološkom porodicom, odnosno plan o napuštanju hraniteljske porodice. Sve navedeno ukazuje na to da je manje problema u ponašanju i više prosocijalnog ponašanja kod dece kada je veza između hranitelja i deteta trajala duže, kada su u srodničkom odnosu koji podrazumeva više bliskosti od samog početka hraniteljstva, kad su više usmereni jedno na drugo - bez biološke dece hranitelja, i kada ovaj odnos ima izgleda da traje duže vreme. Drugim rečima, kada postoji prostor za razvoj emotivne povezanosti između dece i hranitelja, kada se deca osećaju prihvaćeno, i ne strepe od separacije, dolazi do redukcije problema u ponašanju i porasta nivoa prosocijalnog ponašanja. Tumačenje ovih rezultata je izostalo $\mathrm{u}$ istraživanjima koja su do njih došla. Jedan od mogućih razloga za to jeste odsustvo teorijskog okvira na osnovu kog bi autori dali smisao ustanovljenim povezanostima. Pomenute rezultate bilo bi pogodno diskutovati iz ugla Teorije afektivne vezanosti: situacije u kojima su deca pokazala napredak odgovaraju odnosu u kome između deteta i hranitelja postoji sigurna afektivna vezanost - hranitelji su dostupni i responzivni na potrebe deteta i dete ih doživljava kao osobe koje će i ubuduće biti tu da pruže zaštitu i osećaj sigurnosti. Ovaj rezultat dobio bi na još većem značaju da su autori ispitali obrasce afektivne vezanosti hranitelja, čime bi se ustanovilo da li, i u kojoj meri, lične karakteristike hranitelja imaju udela u ovom pozitivnom uticaju na razvoj dece. Ovu potrebu prepoznali su autori koji su ispitivali upravo efekte kvaliteta afektivne vezanosti hraniteljica na prelazak dece iz nesigurnih obrazaca u sigurni obrazac vezanosti. Rezultati dobijeni u istraživanjima sprovedenim na mlađoj deci (uzrasta do 3 godine) ukazuju da deca koja su bila nesigurno vezana, kada se nađu uz sigurno vezane hraniteljice vrlo brzo počinju da manifestuju ponašanje karakteristično za sigurni obrazac. Optimizam u pogledu daljeg razvoja dece i prevazilaženja traumatskih iskustava, koji budi ovaj rezultat, u izvesnoj meri je doveden pod znak pitanja istraživanjem nemačkih autora na deci starijeg uzrasta. Njihovi rezultati ukazali su na to da se deca ponašaju na siguran način sa konkretnim hraniteljem, ali da u sebi nose ideje o emotivnim vezama koje odgovaraju nesigurnim tipovima vezanosti. Na osnovu ovih rezultata neosnovano je praviti prognoze o tome kakve će odnose deca sa različitim tipom vezanosti na bihevioralnom i reprezentacionom planu praviti u kasnijem životu.

Sumirajući rezultate navedenih studija možemo da zaključimo da su adolescenti uspešniji u tranziciji iz hraniteljstva u samostalnost kada su izgradili socijalnu podršku. 
Takođe, postoje indikacije da na potencijal za formiranje bliskih međuljudskih odnosa može da utiče kvalitet emotivne veze koji deca uspostave sa hraniteljima u ranom detinjstvu. Buduća istraživanja bi trebalo da ispitaju da li su adolescenti koji uspešno koriste socijalnu podršku nakon osamostaljivanja boravili kod hranitelja koje odlikuje sigurna afektivna vezanost. Empirijska potvrda ove povezanosti ukazala bi na potrebu za pružanjem podrše hraniteljima na način da oni samu pređu iz nesigurnih u sigurne obrasce afektivne vezanosti, čime bi se, na dugoročnom planu, unapredili kapaciteti njihovih štićenika za uspešnu tranziciju iz hraniteljske porodice u samostalan život.

\section{Literatura}

Arnett, J. J. (2000) Emerging adulthood: A theory of development form the late teens through the twenties. American Psychologist, 55(5), 469-480.

Bovenschen, I., Lang, K., Zimmermann, J., Forthner, J., Nowacki, K., Roland, I., Spangler, G. (2016). Foster children's attachment behavior and representation: Influence of children's pre-placement experiences and foster caregiver's sensitivity. Child abuse \& Niglect, 51, 323-335.

Fridell Lif, E., Brännström, L., Vinnerljung, B., \& Hjern, A. (2016). Childhood adversities and later economic hardship among Swedish child welfare clients: cumulative disadvantage or disadvantage saturation? The British Journal of Social Work, 47, 2137-2156

Dozier, M., Stovall, K. C., Albus, E. K., Bates, B. (2001). Attachment for Infants in Foster Care: The Role of Caregiver State of Mind. Child Development, 72 (5), 1467-1477.

Duke, T., Farruggia, S., Germo, G. (2017). “I don't know where I would be right now if it wasn't for them": Emancipated foster care youth and their important non-parental adults. Children and Youth Services Review, 76, 65-73.

Goemans, A., Van Geel, M., Vedder, P., (2016). Psychosocial functioning in Dutch foster children: The relationship with child, family, and placement characteristics. Children and Youth Services Review, 56, 30-43.

Kääriälä, A., Hiilamo, H., (2017). Children in out-of-home care as young adults: A systematic review of outcomes in the Nordic countries. Children and Youth Services Review, 79, 107-114.

Kinarsky, A., R. (2017). Fostering success: Understanding the experience of foster youth undergraduates. Children and Youth Services Review, 81, 220-228.

Morton, B., M. (2017). Growing up fast: Implications for foster youth when independence and early adulthood collide. Children and Youth Services Review 82, 156-161.

Nho, C., R., Park, E., H., McCarthy, M, L. (2017). Case studies of successful transition from out-of-home placement to young adulthood in Korea. Children and Youth Services Review, 79, 315-324.

Olson, A., Scherer, D, G., Cohen, A, L. (2017). Decision-making skills of emerging adults aging out of foster care. Children and Youth Services Review, $\underline{82}$, 81-86.

Stovall-McClough, K.C., Dozier, M. (2004). Forming attachments in foster care: Infant attachment behaviors during the first 2 months of placement. Development and Psychopathology, 16, 253-271. 
Sulimani-Aidan, Y. (2017). To dream the impossible dream: Care leavers' challenges and barriers in pursuing their future expectations and goals. Children and Youth Services Review, 81, 332-339.

Turney, K., \& Wildeman, C. (2017). Adverse childhood experiences among children placed in and dopted from foster care: Evidence from a nationally representative survey. Child Abuse \& Neglect, 64, 117-129.

Van IJzendoorn, M. H. (1995). Adult attachment representations, parental responsiveness, and nfant attachment: A meta-analysis on the predictive validity of the adult attachment interview. Psychological Bulletin, 117, 387-403.

Whenan, R., Oxlad, M., Lushington, K. (2009). Factors associated with foster carer wellbeing, satisfaction and intention to continue providing out-of-home care. Children and Youth Services Review, 31 (7), 752-760.

Žegarac, N. (2014). U lavirintu socijalne zaštite - Pouke istraživanja o deci na porodičnom i rezidencijalnom smeštaju. Univerzitet u Beogradu Fakultet političkih nauka.

\title{
TRANSITION FROM FOSTER CARE TO INDEPENDEN- CE: A REVIEW OF CURRENT RESEARCH
}

\author{
Ivan Anđelković, Bojana Pucarević \\ University of Niš, Faculty of Philosophy, Department of Social Policy and Social \\ Work
}

\begin{abstract}
The paper offers a critical review of recently published studies of the factors contributing to a successful transition to indepemdent life by the young in foster care. The review includes research conducted in various cultural contexts, such as the USA, Germany, Norway, Korea, Israel, as well as our own country. Our aim has been to describe the considerable achievents in this field, and point out the importance of those results which have been confirmed in more than a single research - specifically, the crucial role of social support in a successful passage to independent life. In addition to being established as culturally universal, this result has been obtained both in the studies concerned with successful transitions, and those focusing on the difficulties faced by the young people leaving foster care. The review also includes research which adresses the questions of what do the capability and readiness of adolescents to build and rely on social support depend on. In the paper the shortcomings and omissions of the studies examined are also considered and possible perspectives for further research into the complex problems related to leaving foster care are suggested, so that the results of such scientific invetigations might be of greater service in the planning and providing of actual interventions.
\end{abstract}

Key words: foster care, transition, social support, research review

\section{Citiranje članka:}

Anđelković, I. i Pucarević, B. (2020). Tranzicija iz hranizeljstva u samostalnost - prikaz istraživanja. Godišnjak za pedagogiju, 5(2), 61-71. 